\title{
Staphylococcus epidermidis: how to turn from commensal to be a pathogen lifestyle
}

Titik Nuryastuti

Department of Microbiology, Faculty of Medicine, Universitas Gadjah Mada, Yogyakarta, Indonesia

DOI: http://dx.doi.org/10.19106/JMedSci005001201813

\begin{abstract}
Staphylococcus epidermidis normally is a commensal inhabitant of healthy human skin and mucosa, but also a common nosocomial pathogen in immunocompromised patients, neonates, and patients with indwelling medical devices. To distinguish the pathogen and commensal strain is a big challenge when identifying this agent with its related infection. This mini-review aims to summarize recent research in this area with a special emphasis on the virulence factor of generating genotypic and phenotypic diversity in S. epidermidis. By living between a commensal and pathogen, S. epidermidis needed to establish many strategies to face different clinical environments, including the new ecological niche of biomaterials. In addition, the growing number of immunocompromised patients increased the risk for a very sensitive host. However, further exploration of the relationship between virulence factor and in vivo pathogenesis is still needed. According to the virulence factor of these bacteria, which are considered as a real pathogen, strict control measures should be taken for $S$. epidermidis infection.
\end{abstract}

\section{ABSTRAK}

Staphylococcus epidermidis merupakan bakteri komensal kulit dan mukosa pada manusia, tetapi akhir-akhir ini banyak ditemukan sebagai agen patogen infeksi nosokomial terutama pada pasien immunocompromised, neonatus, dan pasien dengan peralatan medis invasif. Saat ini, bagaimana membedakan $S$. epidermidis strain patogen dan komensal masih merupakan tantangan besar, baik di laboratorium maupun bagi klinisi. Tinjauan ini bertujuan untuk mendiskusikan peran faktor virulensi $S$. epidermidis dalam menyebabkan keragaman genotipik dan fenotipik serta keterkaitannya dengan perubahan karakterisitik S. epidermidis, sebagai bakteri komensal maupun patogen. Dengan hidup di antara pola komensal dan patogen, $S$. epidermidis perlu menyusun banyak strategi untuk menghadapi lingkungan klinis yang beragam, termasuk beradaptasi dengan permukaan biomaterial yang merupakan bahan dari peralatan medis invasif. Selain itu, meningkatnya jumlah penderita immunocompromised, menyebabkan peningkatan kepekaan host terhadap infeksi S. epidermidis. Namun, penelitian lebih lanjut tentang hubungan antara faktor virulensi dan patogenesis infeksi in vivo masih diperlukan. Dengan pertimbangan bisa berperan sebagai bakteri patogen, tindakan pengendalian yang ketat harus dilakukan untuk infeksi $S$. epidermidis.

Keywords: Staphylococcus epidermidis - commensal - pathogen - virulence factor biofilm

Corresponding author: t.nuryastuti@ugm.ac.id 


\section{INTRODUCTION}

Staphylococcusepidermidis is a coagulasenegative Staphylococcus, considered as a part of the normal mucosa and skin microflora of humans and other mammals. ${ }^{1,2}$ It is considered as a member of the Staphylococci genus, which are gram-positive bacteria belonging to the family Staphylococcaceae. They are clustering, non-motile and non-spore forming cocci, facultative anaerobes and produce catalase. Currently, there are 35 known species of the genus Staphylococcus, from which 15 species are indigenous to humans, while the others are non-human pathogens. ${ }^{2,3}$ Coagulasenegative staphylococci (CNS) are grouped together as Staphylococcus saprophyticus (S. saprophyticus), Staphylococcus lugdunensis (S. lugdunensis), Staphylococcus schleiferi (S. schleiferi), Staphylococcus haemolyticus (S. haemolyticus), Staphylococcus caprae (S. caprae) or S. epidermidis based on their inability to clot blood plasma. Coagulasenegative staphylococci are widely distributed over the surface of the human body, where they constitute the majority of the commensal bacterial skin microflora. ${ }^{1}$

Culture analysis has revealed that Staphylococcus spp. are the most abundant organisms colonizing moist areas. These moist sites include the umbilicus, the axillary vault, the inguinal crease (side of the groin), the gluteal crease, the sole of the foot, the popliteal fossa (behind the knee), nares anterior, and the antecubital fossa (inner elbow). ${ }^{1}$ Staphylococci occupy an aerobic niche on the skin and probably use the urea present in sweat as a nitrogen source. ${ }^{3}$ In spite of being a saprophyte and opportunistic bacterium, this bacteria is involved in balancing the epithelial microflora and serves as a reservoir of resistance genes, which might be transferred to the closely related but more virulent organisms, such as Staphylococcus aureus (S. aureus). ${ }^{4}$ Accordingly, $S$. epidermidis maintains a commonly mutualism relationship with its host and serves as a shield, preventing colonization of potentially more harmful bacteria by producing lantibiotics, which are lanthionine-containing antibacterial peptides, also known as bacteriocins that may provide an added level of protection against certain common pathogens. Additionally, acting as skin microbiome, this bacteria promote the integrity of cutaneous defence through elicitation of host immune responses. ${ }^{4,5}$ As an innocuous commensal microorganism, $S$. epidermidis was for a long time seen as an virulent species. However, today this bacterium is considered the most frequent cause of healthcare associated infections (HAIs), namely those related with indwelling medical devices. Overall, S. epidermidis is the most common species in HAIs, followed by S. haemolyticus, S. hominis, and S. capitis. ${ }^{6-8}$ it has not been established that adherence and biofilm formation are closely linked phenotypes for clinical isolates. In this study, the initial adhesion to different materials (acrylic and glass For example, S. epidermidis may be involved in prosthetic joint, vascular graft, surgical site, central nervous system shunt and cardiac device infections..$^{5,9-11}$

In contrast to $S$. aureus, $S$. epidermidis does not produce many aggressive virulence factors, and consequently the infections caused are, at least in immunocompetent patients, often low-grade and chronic. For severely immunocompromised patients, S. epidermidis may develop into a life-threatening pathogen triggering septicaemia, meningitis, and other serious conditions ${ }^{1,12}$ Staphylococcus epidermidis infections mostly are considered as being extremely recalcitrant to therapy. This is due to high antibiotic resistance rates among nosocomial S. epidermidis isolates, 
but treatment failure is also associated with the ability of $S$. epidermidis to form biofilms on inert surfaces of medical devices from where these sticky, multilayered aggregates of bacteria are hard, if at all possible, to completely remove. ${ }^{13,14}$

Additionally, the increasing use of biomaterials in modern medicine has improved the quality of life of many patients. However, as a drawback, the occurrence of biomaterialassociated infections (BAI) is increasing and now becoming a serious health threat to patients, as well as a financial burden to the society. S. epidermidis, generally regarded as an opportunist pathogen, is now recognised as a real "new" pathogen, since it is the major etiologic agent of BAI. ${ }^{10,11,15}$ Biomaterialassociated infections is generally related to microbial biofilm formation, defined as a microbial community encased in a matrix of self-produced extracellular polymeric substances (slime). Slime affects antimicrobial resistance as well as the effectiveness of the host immune system ${ }^{14,16}$. Currently, no effective non-invasive technique exists to prevent or destroy biofilms associated with BAI. Systemic antibiotics predominantly attack a biofilm infection through the outermost layers of the biofilm, which are usually ineffective as bacteria continue to grow from the inner layers combined with an increased production of extracellular polymeric substances. This virulence constitutes the main reason why biomaterial implants related to an infection nearly always have to be removed. ${ }^{17}$ In addition, the use of antibiotics and disinfectants in hospitals puts a high selective pressure on bacteria to select for resistant and well-adapted variants. ${ }^{18,19}$ However, this unique pattern does not yet explain why just $S$. epidermidis and not any other bacteria, was able to conquer and occupy this novel ecological niche.
Notably, it has been shown that the genomic structure of $S$. epidermidis represents an amazingly versatile microorganism living in a grey area between commensalism and pathogenicity. S. epidermidis employs sophisticated regulatory networks to quickly adapt its metabolism to changing external conditions, to communicate with its neighbours in the same ecological niche, or to escape the host's immune response. ${ }^{8,20}$ Genomic analyses demonstrated the presence of numerous mobile genetic elements in $S$. epidermidis genomes, including methicillin resistance-mediating SCCmec elements and insertion sequences (IS). IS elements seem to be important driving forces that keep the $S$. epidermidis genome extremely flexible and trigger heterogeneous gene expression. ${ }^{21}$ It is suggested that well-adaptability properties both on the regulatory and genetic level might have contributed to the evolutionary success of $S$. epidermidis as a nosocomial pathogen. ${ }^{8}$ Meanwhile, due to the ubiquitous prevalence of $S$. epidermidis as a commensal bacterium, clinicians often face the challenge to decide whether an isolate represents the causative agent of an infection or an unspecific culture contamination. Nowadays, our understanding of how $S$. epidermidis becomes a commensal or pathogen is far from complete and many questions still remain. This review addresses the questions concerning how the recent mechanism of commensal and infectious lifestyles of $S$. epidermidis takes place, which more focusing on literature about virulence properties of $S$. epidermidis i.e biofilm formation, icaADBC presence and the mechanism of regulating gene expression, the role of small colony variant and methicillin resistance gene, as well as its genomic flexibility. 


\section{DISCUSSION}

\section{Biofilm formation, major pathomechanism of HAIs infection}

One of the main virulence characteristics of S. epidermidis is related with their adhesion to substratum surfaces and subsequent biofilm formation..$^{5,10} \mathrm{~A}$ biofilm is a population of cells growing on a surface and enclosed in a selfproduced matrix of extracellular polymeric substance (EPS). Biofilms are notoriously difficult to eradicate and are a source of many recalcitrant infections. ${ }^{14}$ Bacterial biofilm formation comprises a number of physical, biological, and chemical processes. The relative contribution of each process changes throughout biofilm development and depends on prevailing environmental and hydrodynamic conditions. ${ }^{22}$ In general, biofilm formation can be described in five phases ${ }^{5,23,24}$ as shown in FIGURE 1.

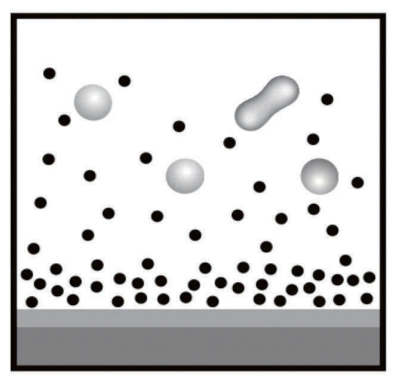

1. Conditioning film

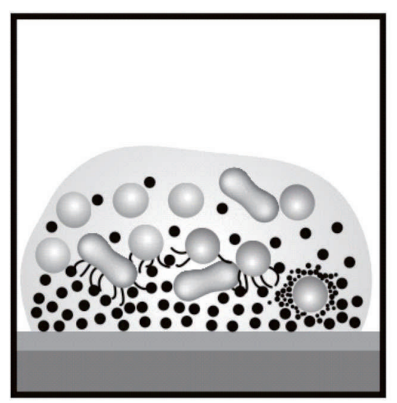

3. Irreversible adhesion and matrix formation

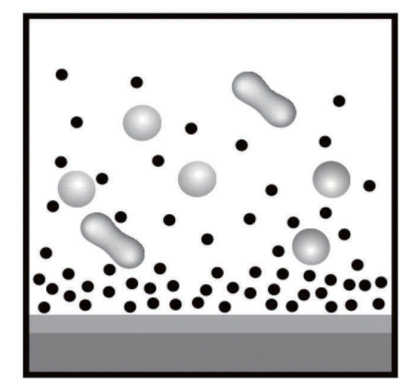

2. Reversible bacterial adhesion

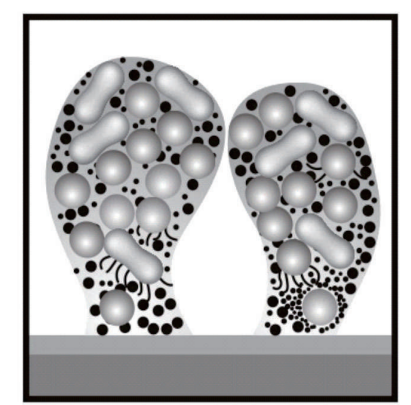

4. Biofilm formation

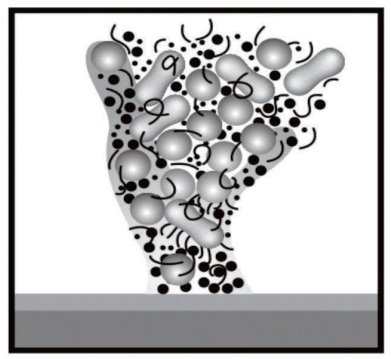

5. Cell detachment

FIGURE 1. The phases of biofilm formation in S. epidermidis. Graphs were modified from Vuong et al., Nuryastuti, and Bos et al.5,23,24 
Substratum surfaces will first become covered with a conditioning film consisting of proteins and glycoproteins, such as fibronectin, vitronectin, fibrinogen, albumin, and immuno-globulins, many of which serve as binding ligands to receptors on colonizing bacteria, although adhesion can also occur to bare substratum surfaces. Biofilm formation continues with the transport of bacteria to the substratum-liquid interface, which is governed by a combination of transport mechanisms, including Brownian motion, gravity, diffusion, convection, or the intrinsic motility of a microorganism. ${ }^{23,24}$ Subsequently, in the second phase, microbial adhesion may occur which is initially of a reversible nature. Factors involved in the initial adhesion to a substratum surface include non-specific interactions originating from both the bacterial cell and substratum surfaces. These non-specific interactions are governed by physicochemical properties such as surface charge, hydrophobicity, and chemical structure of both the bacteria and substratum surface. In the third phase, reversible adhesion of bacteria changes to irreversible, amongst others due to protein-protein interactions and the production of EPS. The fourth phase in biofilm formation is surface colonization. Adhering bacteria grow and divide, forming microcolonies that are considered to be the basic organizational units of a biofilm. Entrapment of other planktonic bacteria in the EPS also occurs, resulting in a multi-layered and mature biofilm. $^{5,23}$ The last step is detachment of individual bacteria or aggregates, which allows bacteria to disseminate into other areas for further surface colonization. In the clinical setting, this last step generally leads to severe systemic infections. ${ }^{5}$ As a pivotal structural component of microbial biofilms, EPS has received much attention. In general, EPS consists of polysaccharides, eDNA and proteins in a hydrated environment. ${ }^{26,27}$ Recently eDNA was found to be a major structural component of bacterial EPS where it plays a role in bacterium-surface and bacterium-bacterium interactions. The EPS produced by $S$. epidermidis consists mostly of polysaccharide intercellular adhesin (PIA). ${ }^{26}$

\section{icaADBC and the mechanism of regulation of expression}

Production of PIA, a key virulence factor of S. epidermidis, is subject to on-off switching, resulting in phenotypic variability (phase variants). ${ }^{11,15,28}$ Polysaccharide intercellular adhesion production is stimulated through the action of membrane bound sensory proteins within the bacterial cell wall. Polysaccharide intercellular adhesion synthesis is catalyzed by proteins encoded within the ica operon, a gene cluster consisting of icaADBC. The icaA gene product is a transmembrane protein with homology to $\mathrm{N}$-acetyl-glucosaminyltransferases. The functions of $i c a B$ and $i c a C$ are less well defined. However, icaB is likely to be secreted while $i c a C$ is predicted to be an integral membrane protein. icaD might act as a link between icaA and icaC and represent a novel enzyme combination. When $i c a A$ is co-expressed with $i c a D$, the transferase activity increases 20 fold. ${ }^{11,29}$

Extracellular polymeric substance production is vital, but metabolically expensive for $S$. epidermidis and therefore wellregulated (FIGURE 2). Regulation of icaexpression and biofilm formation is negatively controlled by the ica operon regulator, IcaR and teiocoplanin-associated locus regulator, TcaR. It is also influenced by environmental conditions that are potentially toxic for the bacterial cell. The exposure of $S$. epidermidis to a high osmolarity, high temperature, detergents, urea, ethanol, the presence of sub-MIC (Minimal Inhibitory Concentration) 
concentrations of certain antibiotics, glucose, iron limitation and oxidative stress have all been shown to elevate ica-expression and biofilm formation. ${ }^{30-32}$ Moreover, the global stress response factor $\sigma \mathrm{B}$, positively regulates $i c a$-expression by negatively regulating $i c a R$ expression, while staphylococcal accessory regulator $\mathrm{A}(\operatorname{sar} A)$ and regulators of sigmaB $(r s b U)$ act similarly. ${ }^{33}$ In addition, the LuxS system involved in quorum sensing in $S$. epidermidis, recently emerged as another negative regulator of biofilm formation. ${ }^{11}$

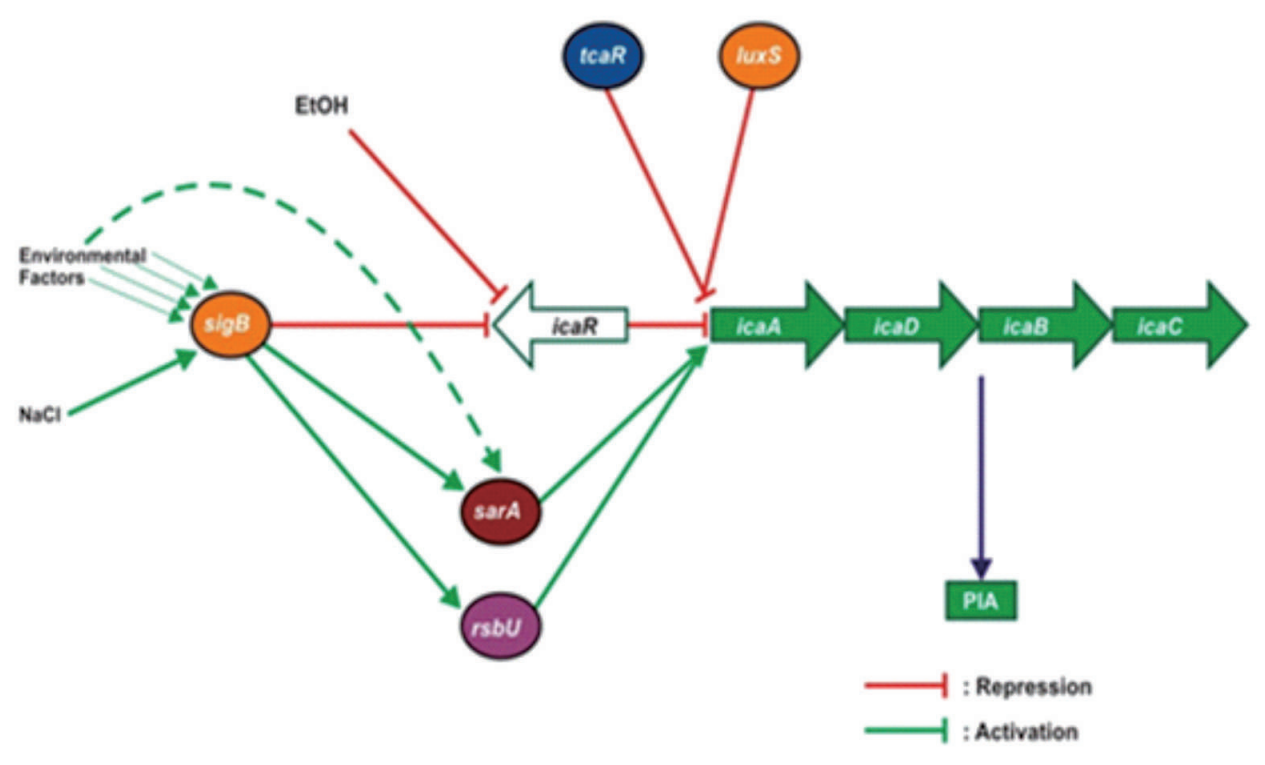

FIGURE 2. The schematic overview of regulatory network controlling expression of icaADBC in S. epidermidis. Graphs were modified from Nuryastuti.23

The genetic and molecular basis of biofilm formation in S. epidermidis is multi-faceted. It has been reviewed that there are two distinct mechanisms of biofilm development; through an ica-dependent and an ica-independent mechanism of biofilm development. ${ }^{11}$ Biofilm production by ica operon-encoded enzymes is currently the best-understood biofilm mechanism in staphylococci, ${ }^{11}$ which is regulated by several regulatory genes such as icaR, $o B, r s b U$ and $\operatorname{sar} A$, including the reversible integration of the IS256 into those genes. ${ }^{28,34}$ Additionally, a surface protein homologous to biofilm-associated protein (Bap), accumulation-associated protein (Aap), and considerable amounts of extracellular teichoic acids (ECTA) ${ }^{8}$ have been identified to be involved in ica-independent biofilm formation in some $S$. epidermidis, which is also under control of the sarA regulatory gene. ${ }^{11}$ 
Recent studies imply that the multicellular organization of bacteria in a biofilm is a crucial mechanism in resisting unfavorable conditions. ${ }^{35}$ Heterogeneous gene expression is typically observed in clinical S. epidermidis strains, and it is assumed that this ability is an advantage for adaptation of staphylococci to changing environmental conditions. ${ }^{8}$ Phase variation involves both regulatory pathways, e.g. in response to environmental signals, as well as genetic variations, by local genomic re-arrangements, altered activity of regulatory proteins or modulation of transcription or translation of the appropriate gene through strand slip mechanisms. ${ }^{8,11,23}$

Polysaccharide intercellular adhesin is the most important component of the staphylococcal slime and its production is catalyzed by proteins encoded within the icaADBC operon. Different S. epidermidis strains vary widely in the degree of PIA or slime, and biofilm they produce. ${ }^{5,36}$ The importance of the ica operon has been confirmed in numerous epidemiological studies, which found a higher prevalence of the ica genes in clinical than in control skin isolates. ${ }^{37,38}$ Clinical strains of $S$. epidermidis obtained from urinary tract infection, ${ }^{39}$ as well as from paediatric cancer patients receiving chemotherapy are reported to be related with ica-presence. ${ }^{25}$

Epidemiological studies have shown that the icaADBC operon is a typical feature of nosocomial $S$. epidermidis strains obtained from device-associated infections. 10,33 It is shown that icaADBC operon is mostly prevalent in strains associated with intravascular catheter-associated bacteraemia and septicaemia. ${ }^{10,39} \mathrm{~A}$ study of the occurrence of ica operon among S. epidermidis isolates obtained from various origins has indicated that the genetic information for biofilm formation is rarely found in isolates obtained outside of hospital settings. ${ }^{18}$ Interestingly, many of these studies found that invasive $S$. epidermidis strains significantly more often carried icaADBC than colonizing commensal $S$. epidermidis strains. Therefore, icaADBCnegative $S$. epidermidis strains were regarded as non-virulent and it was proposed to use ica $A D B C$ as a genetic marker to distinguish invasive and contaminating $S$. epidermidis in blood cultures. ${ }^{37,38}$

\section{Phenotypic and genotypic instability of biofilm-forming ability}

Phenotypic variation in ica-presence is commonly observed in $S$. epidermidis. 8,28,40 Ziebuhr and coworkers identified an insertional element (IS256) that was capable of inserting itself into the ica-locus resulting in ica-negative phenotypes. $^{8}$ This disruption was shown to be reversible as precise excision from the ica-locus which observed at low incidence resulting in ica-positive phenotypes.

We and others have shown that a significant proportion (42-85\%) of clinical isolates are $i c a$-negative during culturing in the laboratory. ${ }^{28,40}$ In contrast to studies showing a reversible switching (phenotypic switching) between ica-positive and ica-negative phenotypes, the ica-locus was permanently lost in these strains. The absence of IS256 and phenotypic variation in these clinical S. epidermidis isolates and the inability to switch back to ica-positive suggested a new mechanism of switching in terms of biofilm formation involving genetic instability. ${ }^{28}$

We showed that the presence of the ica-locus in clinical isolates represents a disadvantage for growth in laboratory conditions. In line with this, it was recently suggested that the presence of the icaADBC operon represents a disadvantage when $S$. epidermidis colonizes the skin. ${ }^{3,28}$ 
Strains that have a high level of PIA production have a significant growth disadvantage under commensal conditions and are therefore outcompeted by strains with more moderate or absent PIA production. Whereas PIA production enables staphylococci to survive and grow under hostile, infection related conditions (biofilms), during commensal colonization (as well as during planktonic growth), PIA production can be considered a burden that can easily be subsided. It is important to conclude that the ability to express different slime-producing phenotypes could provide staphylococci with a greater degree of flexibility for colonizing a range of different environments. ${ }^{33}$ Too much or no PIA production is only favourable under specific conditions while the ability to regulate PIA production allows the organism to adapt to all conditions, both commensal and infectious. ${ }^{23}$

Other studies have found, in $S$. epidermidis, IS256 detection is attributed to the epidemic biofilm-forming clonal lineages, and the element has been shown to trigger heterogeneous biofilm expression by reversible transposition into biofilmassociated genes and regulators. ${ }^{21,41}$

Thus, IS256 was shown to cause phase variation of icaADBC operon expression by alternating insertion in and precise excision from the PIA synthesis-mediating gene locus. ${ }^{20}$ While switch-off of PIA production through IS256 insertions occurs with a frequency of approximately $10^{-6}$ per cell and generation, restoration of PIA-dependent biofilm formation by precise IS256 excision was found to be an extremely rare event $\left(10^{-11}\right.$ per cell and generation). ${ }^{42}$

\section{The role of small colony variant (SCV)}

Small colony variants are naturally occurring subpopulations of bacteria demonstrating distinctive phenotypic characteristics and pathogenic traits. Phenotypically, SCVs have a slow growth rate, atypical colony morphology associated with the formation of pinpoint or 'fried egg' colonies and unusual biochemical features. It was most extensively studied for staphylococci, especially for $S$. aureus as well as $S$. epidermidis. ${ }^{43} \mathrm{SCV}$ s were recorded as being $<1 \mathrm{~mm}$ in size (less than $1 / 10$ of the normal cell size), with reduced pigmentation and haemolytic activity as described in literature. ${ }^{43,44}$ The tiny size of SCVs on solid agar is often due to auxotrophy for haemin and/or menadione, two compounds involved in the biosynthesis of electron transport chain components, which is associated with defects in electron transport and, consequently, altered membrane potential. The abnormal membrane potential, in turn, may confer on these variants innate resistance to aminoglycosides, since the ability of these antibiotics to gain access to intracellular target sites depends on the proton motive force. More importantly, some reports have linked bacterial SCVs to several recurring infections that are intractable to conventional treatment antibiotic regimes. ${ }^{44-46}$

Small colony variants have been associated with long-lasting, chronic, and recurrent infections, and it was suggested that this property was linked to the ability of SCVs to survive intracellularly, thereby being protected from the host immune system and the action of antibiotics. Both biofilm formation and the SCV phenotype may contribute to the recurrence and persistence of staphylococcal infections; bacteria are either embedded in large, adherent biofilms on the surfaces of implanted foreign bodies or may persist intracellularly in phagocytes, such as epithelial or endothelial cells, and thus evade the host immune system. ${ }^{44,45}$ Additionally, it was proved that in vitro experiment using menadione auxotrophs of $S$. aureus and haemin auxotrophs of $S$. epidermidis ${ }^{46}$ 
resulted in the upregulation of alternative sigma factor $B$, which plays a central role in the augmentation of icaADBC expression and PIA production. ${ }^{43,47}$

\section{Methicillin resistance gene}

In addition to biofilm formation, nosocomial $S$. epidermidis isolates are characterized by their pronounced resistance against commonly used antibiotics including methicillin. Methicillin resistance is, similar with $S$. aureus, mediated by the mecA gene encoding a penicillin binding protein with reduced affinity to $\beta$-lactam antibiotics. ${ }^{48}$ However, in contrast to methicillin-resistant $S$. aureus (MRSA), attention paid to methicillin resistant $S$. epidermidis (MRSE) in hospital settings is not adequate enough, meaning they are not dealt with by using intense hygienic measures as those for MRSA. As a result, methicillin resistance rates among nosocomial $S$. epidermidis isolates and other CoNS are extremely high and regularly exceed those of MRSA. ${ }^{48-50}$ It has been reported approximately $80 \%$ of $S$. epidermidis isolates from deviceassociated infections are considered as MRSE, and also found to be multiresistant; whereas commensal strains obtained from the community are mostly methicillin-sensitive $S$. epidermidis. ${ }^{10}$

The mecA gene and its regulators are located on large DNA elements that are termed staphylococcal cassette chromosome mec (SCCmec). In addition to the methicillin resistance determinant, $\mathrm{SCCmec}$ carry a set of recombinases and a wide variety of mobile DNA elements such as transposons, insertion sequences or integrated plasmids. ${ }^{1,15}$ To date, five major SCCmec types have been identified, all of them can be distributed over the $S$. epidermidis genome. Interestingly, SCCmec have been shown to be transferable among staphylococcal species. These genes are now regarded as mobile elements in which extensive recombination and gene shuffling takes place. ${ }^{15,51}$ Obviously, they do not only serve as shuttles for the transfer of methicillin resistance but can also carry other staphylococcal genes. MRSE is often associated with additional antibiotic resistance, such as erythromycin (encoded by erm genes), ciprofloxacin, clindamycin, aminoglycosides (encoded in aacA/aphD gene) or trimethoprim-sulfamethoxazole. ${ }^{15}$ The recent findings of genomic research strongly suggest that $S$. epidermidis and other coagulase-negative staphylococci represent the gene pool for the ongoing generation of novel SCC types from which methicillin resistance in $S$. aureus might originate. ${ }^{1,12}$ Accordingly, it would be meaningful and reasonable to control MRSE and MR-CoNS by appropriate hygiene measures in a similar manner for MRSA, in order to lower MRSA burden in medical facilities, due to their role as reservoirs for the spread of resistance genes within microbial communities.

\section{Genomic flexibility}

It was demonstrated that clonal diversification in $S$. epidermidis is mainly based on genetic recombination, which is in contrast to $S$. aureus, a species known to evolve preferentially by point mutations. ${ }^{21,41}$

Multilocus sequence typing (MLST) analysis of a representative collection of clinical S. epidermidis isolates revealed a high degree of genetic diversity within the species, but the most widespread clone was ST2 or ST27 (sequence types). Especially, clonal complex ST2 isolates were found to be highly flexible with respect to methicillin resistance and prone to take up these mobile genetic elements. ${ }^{21}$ Possibly, the successful spread of ST2 may be due to the fact that all ST2 isolates contain IS256 insertion sequences and ica genes, two factors that may have determinants to enhance transmissibility, persistence, or 
invasiveness in S. epidermidis. In addition, most ST2 isolates show in vitro capacity to form biofilms..$^{15,21}$

Instability of genetic material is often an indication of mobility, and in this respect it is also conceivable that the ica operon represents mobile DNA that has been lost in the commensal strain. S. epidermidis isolates ST 2(ST27) represent an ideal genetic background for biofilm and resistance genes, resulting in well-adapted strains which are then selected in the hospital environment and causes device-related infection and bacteraemia. The presence of multiple copies of IS256 in the ST27 genome might support this adaptation process by an ongoing generation of novel phenotypic and genotypic variants. Therefore, the combination of biofilm formation, antibiotic resistance, and genetic flexibility may explain why ST2 has become the dominant clonal variant within medical facilities. ${ }^{8,41}$

\section{Clinical manifestation of related infection}

Staphylococcus epidermidis and other CoNS have for a long time been dismissed as culture contaminations which is mainly due to the fact that CoNS are primarily ubiquitous commensals of the human skin and mucosa. It is still a great challenge for the clinical microbiology laboratory to distinguish infecting strains from contaminants. In suspected $S$. epidermidis infections, where the pathogen is also a skin commensal that could contaminate skin swab or blood specimen if aseptic techniques are not followed, the same indistinguishable microorganism must be cultured from at least two separate specimens in order to differentiate a relevant infection from skin contamination. ${ }^{52}$ In contrast, for virulent species such as $S$. aureus or gram negative bacteria, a single positive clinical specimen may be sufficient to determine the presence of a recent infection. ${ }^{53,54}$ However, some groups of the population are prone to be infected with this microorganism. These higher risk groups include preterm neonates, immunocompromised individuals and patients with indwelling medical devices. ${ }^{1,5,10}$

The most important clinical manifestation associated with CoNS, particularly $S$. epidermidis is biomaterial-associated infections (BAI), which include a unique, complex constellation of many factors that have to be considered for their successful management. ${ }^{33}$ The increasing use of foreign materials in almost all fields of modern medicine is associated with a risk of bacterial infection. ${ }^{10}$ Morbidity and mortality of biomaterial-associated infections may vary according to the underlying patient condition, the microbial strain(s) that are implicated, and the type of device. Biomaterial-associated infections contribute significantly to the increasing problem of nosocomial infections. While a variety of microbial strains have been involved as causative organisms in biomaterial-associated infections, staphylococci, particularly $S$. epidermidis, account for the majority of infections related to both temporarily inserted and permanently implanted biomaterials. ${ }^{5,10}$

The presence of a biomaterial significantly compromises the host's ability to cope with infectious microorganisms. These microorganisms can reach a biomaterial implant in several ways and at different times post-implantation. Airborne microorganisms, inevitably present in the operating theater, can reach a biomaterial implant surface as early as before the implantation. Also during insertion of a biomaterial implant, microorganisms from the commensal microflora of the skin can contaminate a biomaterial implant. Perioperative contamination is believed to be the most common cause of biomaterial associated infection. ${ }^{10,18,33}$

Bacteria that adhere to implanted medical 
devices or damaged tissue can encase themselves in a hydrated matrix of extra cellular polymeric substances, a slimy layer, and start growing into a biofilm. Bacteria organized in biofilms are at least 10-1000 times more resistant to antibiotics ${ }^{14,16}$ and can cope much better with unfavorable external conditions as the host immune system than their planktonic counterparts. The biofilm mode of growth represents a benefit for staphylococcal strains enabling them to colonize inert surfaces of medical devices. ${ }^{8}$ Antibiotic resistance of bacteria in the biofilm mode of growth contributes to the chronic nature of these infections, which are notoriously difficult to resolve. The mechanisms of bacterial resistance in biofilms are different from the now familiar plasmids, transposons, and mutations that convey innate resistance to individual bacterial cells. In biofilms, resistance seems to depend on multicellular strategies resulting in an impaired penetration of antibiotics to the target organisms and a decreased immune response. ${ }^{14,55}$

Biomaterial-associated infections comprise local (e.g., exit site) and systemic infections. Originating from bacteremia or other systemic spread of causative organisms and depending on the nature and localization of the biomaterial inserted, sepsis, endocarditis, meningitis, joint sepsis, vertebral abscesses, and other local manifestations due to metastatic seeding may result. ${ }^{1,19}$ These comprise infections commonly associated with prosthetic vascular grafts, prosthetic heart valves, cardiac devices, and coronary stents. Moreover, local inflammation signs include erythema, warmth, swelling, tenderness, and purulent drainage, which characterize exitsite infections.

It has been shown that $S$. epidermidis was the most frequent agents of central venous catheter (CVC) and umbilical catheterassociated BSIs (Blood Stream Infection) in neonatal ICUs. ${ }^{5,25 \text { the coagulase-negative staphylococci (CoNs }}$ Besides BSIs, the CoNS group may cause further invasive infections in preterm infants, such as infective endocarditis, meningitis, and necrotizing fasciitis. ${ }^{5,12}$ Additionally, $S$. epidermidis is also considered as the main cause of septicemia in febrile patients who suffer from chemotherapy-induced neutropenia, which is accounting for approximately 20 to $40 \%$ of cases. ${ }^{1,25}$

\section{CONCLUSION}

So far it is still a great challenge for clinician to distinguish $S$. epidermidis strains that may cause infection from those that live on the skin. However, the virulence properties identified in this paper, such as the presence of biofilm formation phenotype including icaADBC operon, IS256, mecA, $\mathrm{SCV}$ properties, together with patient characteristics, might be used to consider the pathogenesis of infection caused by $S$. epidermidis. Nevertheless, up to date, the clues to distinguish between infectious and commensal strains of $S$. epidermidis are not clear yet. It is well understood the adhesion to host tissue is considered crucial during both these lifestyles.

Bylivingontheverge of commensalismand pathogenicity, S. epidermidis has elaborated many strategies to overcome different clinical environments, including the new ecological niche of biomaterials. In addition, the growing number of immunocompromised patients increases the risk for a very sensitive host. The formation of biofilms, the acquisition of resistance characteristics and the enormous flexibility of the genome of staphylococci are characteristics that help their survival in specific environments and are the main reasons why staphylococci have become the most successful pathogens in clinical setting. With respect to their possible role as true pathogens, $S$. epidermidis infection should be 
taken more seriously with adequate prevention applications for future infection control and hygiene measures.

\section{ACKNOWLEDGEMENTS}

I would like to thank Prof Henny van der Mei from Department of Biomedical Engineering, University of Groningen, The Netherlands for giving insight and comments that greatly improved this manuscript.

\section{REFERENCES}

1. Becker K, Heilmann C, Peters G. CoagulaseNegative Staphylococci. Clin Microbiol Rev. 2014;27(4):870-926. http://doi:10.1128/ CMR.00109-13

2. Christensen GJM, Brüggemann H. Bacterial skin commensals and their role as host guardians. Benef Microbes. 2014;5(2):20115. http://doi:10.3920/BM2012.0062

3. Grice EA, Segre JA. The skin microbiome. Nat Rev Microbiol. 2013;9(4):244-53. http:// doi:10.1038/nrmicro2537

4. Otto M. Staphylococcus epidermidisthe'accidental'pathogen. Nat Rev Microbiol. 2009;7(8):555-67. http://doi:10.1038/ nrmicro2182

5. Vuong C, Otto M. Staphylococcus epidermidis infections. Microbes Infect. 2002;4(4):481-9. http://doi:10.1016/S1286-4579(02)01563-0

6. Cerca N, Pier GB, Vilanova M, Oliveira R, Azeredo J. Quantitative analysis of adhesion and biofilm formation on hydrophilic and hydrophobic surfaces of clinical isolates of Staphylococcus epidermidis. Res Microbiol. 2005;156:506-514. http://doi:10.1016/ j.resmic.2005.01.007

7. Gomes F, Teixeira P, Oliveira R. Mini-review : Staphylococcus epidermidis as the most frequent cause of nosocomial infections: old and new fighting strategies. Biofouling. 2014;30(2):131-41. http://doi:10.1080/08927 014.2013.848858
8. Ziebuhr W, Hennig S, Eckart M, Kr H, Batzilla C, Kozitskaya S. Nosocomial infections by Staphylococcus epidermidis: how a commensal bacterium turns into a pathogen. Int J Antimicrob Agents. 2006;28S:S14-20. http://doi:10.1016/j.ijantimicag.2006.05.012

9. Garrett TR, Bhakoo M, Zhang Z. Bacterial adhesion and biofilms on surfaces. Prog Nat Sci. 2008;18(9):1049-56. http:// doi:10.1016/j.pnsc.2008.04.001

10. Brescó MS, Harris LG, Thompson K, Stanic $\mathrm{B}$, Morgenstern $\mathrm{M}$, Mahony LO, et al. Pathogenic Mechanisms and Host Interactions in Staphylococcus epidermidis device-related infection. Front Microbiol. 2017;8(1401). http://doi:10.3389/fmicb.2017.01401

11. O'Gara JP. ica and beyond: Biofilm mechanisms and regulation in Staphylococcus epidermidis and Staphylococcus aureus. FEMS Microbiol Lett. 2007;270(2):179-88. http://doi:10.1111/j.1574-6968.2007.00688

12. Suja KRS, Sheela P, Jyothis S, Radhakrishnan EK. Virulence factors associated with coagulase negative Staphylococci isolated from human infections. 3 Biotech. 2017;7(140):1-10. http://doi:10.1007/ s13205-017-0753-2

13. Mack D, Davies AP, Harris LG, Jeeves $\mathrm{R}$, Pascoe B, Knobloch JK, et al. Staphylococcus epidermidis in BiomaterialAssociated Infections. In: T.F. Moriarty et al., editors, Biomaterials Associated Infection: Immunological Aspects and Antimicrobial Strategies. New York: Springer Science Business Media; 2013. p 25-57. http:// doi:10.1007/978-1-4614-1031-7

14. Lewis K. Minireview riddle of biofilm resistance. Antimicrob Agents Chemother.

2001;45(4):999-1007. http://doi:10.1128/ AAC.45.4.999

15. Prasad S, Nayak N, Satpathy G, Nag HL, Venkatesh P, Ramakrishnan S. Molecular \& phenotypic characterization of Staphylococcus 
epidermidis in implant related infections. Indian J Med Res. 2012;136:483-90.

16. de la Fuente-Nunez C, Reffuveille F, Fernandez L, Hancock REW. Bacterial biofilm development as a multicellular adaptation: antibiotic resistance and new therapeutic strategies. Curr Opin Microbiol. 2013;580-9. http://doi:10.1016/j.mib.2013.06.013

17. Wilkins M, Hall-stoodley L, Allan RN, Faust SN. New approaches to the treatment of biofilm-related infections. $\mathrm{J}$ Infect. 2014; 69:S47-52.http://doi:10.1016/ j.jinf.2014.07.014

18. Lindsay D, von Holy A. Bacterial biofilms within the clinical setting: what healthcare professionals should know. J Hosp Infect. 2006;64:313-25 http://doi:10.1016/ j.jhin.2006.06.028

19. Mack D, Davies AP, Harris LG, Jeeves R, Pascoe B, Knobloch JKM, et al. Staphylococcus epidermidis in biomaterialassociated infections. In: T.F. Moriarty et al., editors. Biomaterials Associated Infection: Immunological Aspects and Antimicrobial Strategies. New York: Springer Science Business Media; 2013. p 25-57 http:// doi:10.1007/978-1-4614-1031-7_2

20. Schoenfelder SMK, Lange C, Eckart M, Hennig S, Kozytska S, Ziebuhr W. International Journal of Medical Microbiology Success through diversity - How Staphylococcus epidermidis establishes as a nosocomial pathogen. Int J Med Microbiol. 2010;300(6):380-6. http://doi:10.1016/j. ijmm.2010.04.011

21. Kozitskaya S, Olson ME, Fey PD, Witte W, Ohlsen K, Ziebuhr W, et al. Clonal analysis of Staphylococcus epidermidis isolates carrying or lacking biofilm-mediating genes by multilocus sequence typing. J Clin Microbiol. 2005;43(9):4751-7. http://doi:10.1128/ JCM.43.9.4751
22. Bryers JD. Medical biofilms. Biotechnol Bioeng. 2009;100(1): 1-18. http:// doi:10.1002/bit.21838

23. Nuryastuti T. Environmental signals affecting ica-expression in Staphylococcus epidermidis biofilms. [Dissertation]. The Netherlands: University of Groningen; 2010.

24. Bos R, Mei HC Van Der, Busscher HJ. Physico-chemistry of initial microbial adhesive interactions-its mechanisms and methods for study. FEMS Microbiol Rev. 1999;23:179-230.

25. von Eiff C, Peters G, Heilmann C. Pathogenesis of infections due to coagulase negative staphylococci. Lancet Infect Dis. 2002;2(11):677-85. http://doi:10.1016/ S1473-3099(02)00438-3

26. Rohde H, Frankenberger S, Zähringer U, Mack D. Structure, function and contribution of polysaccharide intercellular adhesin (PIA) to Staphylococcus epidermidis biofilm formation and pathogenesis of biomaterialassociated infections. Eur $\mathrm{J}$ Cell Biol. 2010;89(1):103-11. http://doi:10.1016/j.ejcb. 2009.10.005

27. Cramton SE, Gerke C, Schnell NF, Nichols WW, Gotz F. The intercellular adhesion (ica) locus is present in Staphylococcus aureus and is required for biofilm formation. Infect Immun. 1999;67(10):5427-33.

28. Nuryastuti T, van der Mei HC, Busscher HJ, Kuijer R, Aman AT, Krom BP. recA mediated spontaneous deletions of the icaADBC operon of clinical Staphylococcus epidermidis isolates: A new mechanism of phenotypic variations. Antonie van Leeuwenhoek, Int J Gen Mol Microbiol. 2008;94(2):317-28. http://doi:10.1007/s10482-008-9249-8

29. Arciola CR, Campoccia D, Ravaioli S, Montanaro L. Polysaccharide intercellular adhesin in biofilm: structural and regulatory aspects. Front Cell Infect Microbiol. 2015;5(7):110. http://doi:10.3389/fcimb. 2015.00007 
30. Knobloch JK, Horstkotte MA, Rohde H, Kaulfers P. Alcoholic ingredients in skin disinfectants increase biofilm expression of Staphylococcus epidermidis. J Antimicrobial Chemother. 2002;49:683-7.

31. Cramton SE, Ulrich M, Gotz F, Doring G. Anaerobic conditions induce expression of polysaccharide intercellular adhesin in Staphylococcus aureus and Staphylococcus epidermidis. Infect Immun. 2001;69(6):407985. http://doi:10.1128/IAI.69.6.4079

32. Rachid S, Ohlsen K, Witte W, Hacker RG, Ziebuhr W. Effect of subinhibitory antibiotic concentrations on polysaccharide intercellular adhesin expression in biofilm-forming Staphylococcus epidermidis. Antimicrob Agents Chemother. 2000;44(12):3357-63.

33. Fitzpatrick F, Humphreys H, O'Gara JP. The genetics of staphylococcal biofilm formation-will a greater understanding of pathogenesis lead to better management of device-related infection? Eur Soc Clin Infect Dis. 2005;11(12):967-73. http://doi:10.1111/ j.1469-0691.2005.01274.x

34. Li H, Xu L, Wang J, Wen Y, Vuong C, Otto M, et al. Conversion of Staphylococcus epidermidis strains from commensal to invasive by expression of the ica locus encoding production of biofilm exopolysaccharide. Infect Immun. 2005; 73(5):3188-91. http:// doi:10.1128/IAI.73.5.3188

35. O'Gara JP, Humphreys H. Staphylococcus epidermidis biofilms: importance and implications. J Med Microbiol. 2001;50:5827. http://doi:10.1099/0022-1317-50-7-582

36. Rohde H, Frankenberger S, Zähringer U, Mack D. Structure, function and contribution of polysaccharide intercellular adhesin (PIA) to Staphylococcus epidermidis biofilm formation and pathogenesis of biomaterialassociated infections. Eur J Cell Biol. 2010;89(1):103-11. http://doi:10.1016/j. ejcb.2009.10.005
37. Vandecasteele SJ, Peetermans WE, Merckx RR, Rijnders BJA, van Eldere J. Reliability of the ica, aap and atlE genes in the discrimination between invasive, colonizing and contaminant Staphylococcus epidermidis isolates in the diagnosis of catheter-related infections. Eur Soc Clin Infect Dis. 2003; 9(2):114-9. http:// doi:10.1046/j.1469-0691.2003.00544

38. Chessa D, Ganau G, Spiga L, Bulla A, Mazzarello V. Staphylococcus aureus and Staphylococcus epidermidis virulence strains as causative agents of persistent infections in breast implants. PLoS ONE. 2016; 11(1): e0146668. http://doi:10.1371/journal. pone. 0146668

39. Cafiso V, Bertuccio T, Santagati M, Campanile F, Amicosante G, Perilli MG, et al. Presence of the ica operon in clinical isolates of Staphylococcus epidermidis and its role in biofilm production. Clin Microbiol Infect. 2004;10(12):1081-8. http://doi:10.111 $1 / \mathrm{j} .1469-0691.2004 .01024$

40. Nuryastuti T, Mei HC Van Der, Busscher HJ, Kuijer R, Aman AT, Krom BP. High frequency spontaneous deletions within the icaADBC operon of clinical Staphylococcus epidermidis isolates. I J Biotech. 2012;17(2):144-53.

41. Kozitskaya S, Cho S, Dietrich K, Marre R, Naber K, Ziebuhr W. The bacterial insertion sequence element IS 256 occurs preferentially in nosocomial Staphylococcus epidermidis Isolates : association with biofilm formation and resistance to aminoglycosides. Infect Immun. 2004;72(2):1210-5. http:// doi:10.1128/IAI.72.2.1210

42. Hennig S, Ziebuhr W. A transposaseindependent mechanism gives rise to precise excision of IS 256 from insertion sites in Staphylococcus epidermidis. J Bacteriol. 2008;190(4):1488-90. http://doi:10.1128/ JB.01290-07

43. Bogut A, Niedz J, Kozioł-Montewka M, Strzelec-Nowak D, Blacha J, Mazurkiewicz 
T, et al. Characterization of Staphylococcus epidermidis and Staphyloccocus warneri small-colony variants associated with prosthetic-joint infections. J Med Microbiol. 2014;63:176-85. http://doi:10.1099/ jmm.0.066068-0

44. Eiff C Von, Vaudaux P, Kahl BC, Lew D, Emler S, Schmidt A, et al. Bloodstream Infections caused by small-colony variants of coagulase-negative staphylococci following pacemaker implantation. Clin Infect Dis. 1999;29:932-4.

45. TandeAJ, Osmon DR, Greenwood-quaintance KE, Mabry TM, Hanssen AD. Clinical characteristics and outcomes of prosthetic joint infection caused by small colony variant staphylococci. mBio. 2014;5(5):e01910-14. http://doi:10.1128/mBio.01910-14

46. Laham $\mathrm{N}$ Al. Mini-review: Formation, antibiotic resistance and clinical outcome of infections associated with small colony variants of staphylococci. In: Méndez-Vilas A, editor, Microbial pathogens and strategies for combating them: science, technology and education. Formatex; 2013. p 497-507.

47. Laham N Al, Rohde H, Sander G, Fischer A, Hussain M, Heilmann C, et al. Augmented expression of polysaccharide intercellular adhesin in a defined Staphylococcus epidermidis mutant with the smallcolony-variant phenotype. J Bacteriol. 2007;189(12):4494-501. http://doi:10.1128/ JB.00160-07

48. von Eiff C, Reinert RR, Kresken M, Brauers $\mathrm{J}$, Hafner D, Peters $\mathrm{G}$, et al. Nationwide German multicenter study on prevalence of antibiotic resistance in staphylococcal bloodstream isolates and comparative in vitro activities of quinupristin-dalfopristin. J Clin Microbiol. 2000;38(8):2819-23.

49. Seng R, Leungtongkam U, Thummeepak R, Chatdumrong W, Sitthisak S. High prevalence of methicillin-resistant coagulasenegative staphylococci isolated from a university environment in Thailand. Int Microbiol. 2017;20(2):65-73. http:// doi:10.2436/20.1501.01.286

50. Watanabe S, Ohnishi T, Yuasa A, Kiyota H, Shimizu T, Hatta N, et al. The first nationwide surveillance of antibacterial susceptibility patterns of pathogens isolated from skin and soft-tissue infections in dermatology departments in Japan. J Infect Chemother. 2017;23(8):503-11. http://doi:10.1016/j. jiac.2017.05.006

51. Li M, Wang X, Gao Q, Lu Y, Lu Y. Molecular characterization of Staphylococcus epidermidis strains isolated from a teaching hospital in Shanghai, China. J Med Microbiol. 2009;58:456-61. http://doi:10.1099/ jmm.0.007567-0

52. Kristóf K, Pongrácz J. Interpretation of blood microbiology results - function of the clinical microbiologist. J Int Fed Clin Chem Lab Med. 2016;27(2):147-55.

53. Osmon DR, Berbari EF, Berendt AR, Lew D, Zimmerli W, Steckelberg JM, et al. Diagnosis and management of prosthetic joint infection: clinical practice guidelines by the Infectious Diseases Society of America. Clin Infect Dis. 2013;56(1):e1-25. http://doi:10.1093/cid/ cis 803

54. Baron EJ. The role of the clinical microbiology laboratory in the diagnosis of selected infectious processes. J Clin Microbiol. 2011;49(9Suppl):S25 http://doi:10.1128/ JCM.00842-11

55. Acker $\mathrm{H}$ Van, Dijck $\mathrm{P}$ Van, Coenye $\mathrm{T}$. Molecular mechanisms of antimicrobial tolerance and resistance in bacterial and fungal biofilms. Trends Microbiol 2014; 22(6):32633. http://doi:10.1016/j.tim.2014.02.001 